\title{
The DAF-7 TGF- $\beta$ signaling pathway regulates chemosensory receptor gene expression in C. elegans
}

\author{
Katherine M. Nolan, ${ }^{1,2}$ Trina R. Sarafi-Reinach, ${ }^{1,2}$ Jennifer G. Horne, ${ }^{1}$ Adam M. Saffer, ${ }^{1}$ and \\ Piali Sengupta ${ }^{1,2,3}$ \\ ${ }^{1}$ Department of Biology and ${ }^{2}$ Volen Center for Complex Systems, Brandeis University, Waltham, Massachusetts 02454, USA
}

\begin{abstract}
Regulation of chemoreceptor gene expression in response to environmental or developmental cues provides a mechanism by which animals can alter their sensory responses. Here we demonstrate a role for the daf-7 TGF- $\beta$ pathway in the regulation of expression of a subset of chemoreceptor genes in Caenorhabditis elegans. We describe a novel role of this pathway in maintaining receptor gene expression in the adult and show that the DAF-4 type II TGF- $\beta$ receptor functions cell-autonomously to modulate chemoreceptor expression. We also find that the alteration of receptor gene expression in the ASI chemosensory neurons by environmental signals, such as levels of a constitutively produced pheromone, may be mediated via a DAF-7-independent pathway. Receptor gene expression in the ASI and ASH sensory neurons appears to be regulated via distinct mechanisms. Our results suggest that the expression of individual chemoreceptor genes in C. elegans is subject to multiple modes of regulation, thereby ensuring that animals exhibit the responses most appropriate for their developmental stage and environmental conditions.
\end{abstract}

[Keywords: TGF- $\beta$; C. elegans; chemosensory receptor; dauer]

Supplemental material is available at http://www.genesdev.org.

Received July 29, 2002; revised version accepted October 11, 2002.

Environmental information is acquired by the peripheral sensory system and relayed to multiple circuits to mediate developmental and behavioral changes. The functions of these sensory pathways can be altered in response to changing environmental conditions or in specific life stages. Mechanisms of short-term sensory plasticity have been shown to include the reversible modification of signal transduction molecules in sensory neurons, whereas mechanisms of long-term plasticity involve changes in gene expression, leading to alterations in synaptic strengths (Bailey and Chen 1988; Yin et al. 1994; Finkbeiner and Greenberg 1998; Impey et al. 1998; Pham et al. 1999; Zufall and Leinders-Zufall 2000; Fain et al. 2001). However, for maximum efficiency, it is likely that different sensory modalities use distinct mechanisms to effect sensory plasticity.

Animals sense chemicals in the environment by using their olfactory and gustatory sensory systems. Although olfactory plasticity regulated by environmental conditions and developmental cues has been described in both insects and vertebrates (Kendrick et al. 1992; Wang et al. 1993; Dubin et al. 1995; Brennan and Keverne 1997; Mor-

${ }^{3}$ Corresponding author.

E-MAIL sengupta@brandeis.edu; FAX (781) 736-3107.

Article and publication are at http://www.genesdev.org/cgi/doi/10.1101/ gad.1027702. gan et al. 1998; Shaver et al. 1998), the underlying molecular mechanisms have not been fully defined. The nematode Caenorhabditis elegans provides an excellent model system in which to study the mechanisms by which olfactory behaviors are modulated. Nematodes exhibit robust and sensitive olfactory responses to multiple chemicals using a small and well-defined number of chemosensory neurons (Bargmann and Mori 1997; Troemel 1999b). Chemosensory responses are altered under environmental conditions of overcrowding or starvation (Colbert and Bargmann 1997), long-term exposure to a chemical (Colbert and Bargmann 1995; Bernhard and van der Kooy 2000; L'Etoile and Bargmann 2000), or pairing of a normally attractive chemical with aversive stimuli (Wen et al. 1997; Morrison et al. 1999). Moreover, sensory responses are dramatically changed in specific developmental stages. Under favorable growth conditions in early larval stages, the DAF-7 TGF- $\beta$ (transforming growth factor- $\beta$ ) ligand and insulin-like pe-ptides are secreted by the ASI chemosensory and other unidentified neurons, respectively (Ren et al. 1996; Schackwitz et al. 1996; Pierce et al. 2001). DAF-7 binds the widely expressed DAF-1 and DAF-4 type I and type II TGF- $\beta$ receptors to promote reproductive growth (Georgi et al. 1990; Estevez et al. 1993). However, under adverse environmental conditions, such as high concentrations of a constitutively secreted pheromone, daf-7 expression is 
reduced, and down-regulation of TGF- $\beta$ and insulin signaling triggers entry into the alternative third larval dauer stage (Albert et al. 1981; Golden and Riddle 1982, 1984; Gottlieb and Ruvkun 1994; Ren et al. 1996; Schackwitz et al. 1996). The nervous system and other tissues undergo extensive remodeling in the dauer stage (Albert and Riddle 1983; Riddle and Albert 1997), and dauer animals exhibit distinctive stage-specific sensory behaviors (Hedgecock and Russell 1975; Albert and Riddle 1983; Riddle and Albert 1997).

As suggested previously (Peckol et al. 2001), a simple mechanism by which olfactory behaviors could be modified in C. elegans is via the altered expression of olfactory receptor genes. Similar to other organisms, nematodes respond to odorants using $\mathrm{G}$ protein-coupled receptors (Troemel et al. 1995; Sengupta et al. 1996). However, in contrast to both Drosophila and rodents, C. elegans expresses multiple, partially overlapping sets of receptors in each chemosensory neuron type (Chess et al. 1994; Troemel et al. 1995; Clyne et al. 1999; Gao and Chess 1999; Malnic et al. 1999; Troemel 1999a; Vosshall et al. 1999; Scott et al. 2001). Chemoreceptors expressed in a given neuron type share downstream signal transduction components (Coburn and Bargmann 1996; Komatsu et al. 1996; Colbert et al. 1997; Roayaie et al. 1998; L'Etoile and Bargmann 2000), suggesting that the ability of chemosensory neurons to respond to multiple, structurally unrelated odorants is determined primarily by the set of expressed chemoreceptors. Because each chemosensory neuron expresses multiple chemoreceptors, altering the synaptic efficacy of the circuit would alter the responses to multiple chemicals. However, altering expression of a single chemoreceptor gene would result in a specific change in the response to one or a small subset of chemicals. Consistent with this, misexpression of the olfactory receptor for the normally attractive chemical diacetyl in a neuron type that senses repellents has been shown to be sufficient to trigger avoidance of diacetyl (Troemel et al. 1997). Moreover, it has been shown that exposure to pheromone and entry into the dauer stage results in dramatic alterations of olfactory receptor gene expression in the ASI chemosensory neurons. This modulation may underlie some aspects of the altered chemosensory responses exhibited under conditions of overcrowding or by dauer animals (Peckol et al. 2001). Thus, given the critical role of chemoreceptors in directing the functions of chemosensory neurons in C. elegans, the correct spatial and temporal expression of these genes is likely to be regulated in a complex manner.

In this study, we demonstrate that the daf-7 TGF- $\beta$ pathway regulates the expression of all chemoreceptors known to be expressed in the ASI chemosensory neurons, as well as a chemoreceptor expressed in the ASH sensory neurons. Our results demonstrate that TGF- $\beta$ signaling is required at multiple developmental stages to regulate receptor expression and uncover a previously unknown role of this pathway in maintaining chemoreceptor gene expression in the adult. Additionally, we show that distinct mechanisms regulate chemoreceptor gene expression in the ASI and ASH sensory neurons. These findings suggest that the precise regulation of chemoreceptor genes by multiple mechanisms enables $C$. elegans to exhibit sensory behaviors appropriate for its developmental stage and environmental conditions.

\section{Results}

Expression of a subset of chemoreceptor genes is altered in daf-7 TGF- $\beta$ pathway mutants

The promoter of the candidate chemosensory receptor gene $s r a-6$ drives expression of a GFP reporter in the ASH and ASI sensory neurons in the head and in the PVQ interneurons in the tail (Troemel et al. 1995). In a genetic screen, we isolated a mutant oy8, in which expression of an sra- $6:: g f p$ transgene (henceforth referred to as expression of sra-6) was strongly reduced in both the ASH and ASI neurons but was unaffected in the PVQ neurons (Fig. 1). Subsequent mapping and complementation experiments demonstrated that oy 8 is allelic to the gene daf- 8 , which encodes a SMAD protein (Riddle and Albert 1997).
A

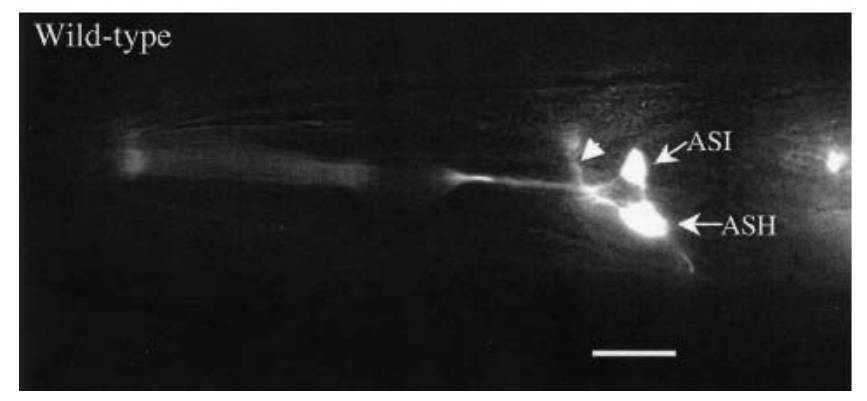

B

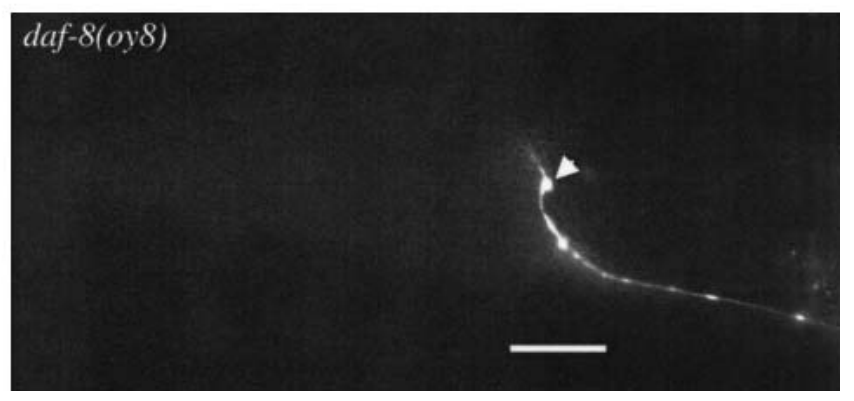

Figure 1. Expression of an $s r a-6:: g f p$ transgene is reduced in the ASH and ASI sensory neurons of daf-8(oy8) mutants. (A) sra-6::gfp is expressed in the ASH and ASI sensory neurons in the head of an adult wild-type animal. This transgene also drives expression in the PVQ interneurons whose cell bodies are present in the tail (not shown). Arrowhead points to the axonal process of the PVQ interneurons in the nerve ring. $(B)$ No or weak sra-6::gfp expression is observed in the ASH and ASI neurons of daf-8(oy8) adult animals. Expression in the PVQ interneurons is unaffected (arrowhead). Lateral view; anterior is at left. Bar, $20 \mu \mathrm{m}$. 
sra-6 expression was affected similarly in an additional daf-8 allele (Table 1).

Because DAF- 8 functions in the DAF-7 TGF- $\beta$-mediated signaling pathway (Malone and Thomas 1994), we determined whether additional components of this pathway are also required for sra-6 expression. Mutations in the daf-7 TGF- $\beta$ ligand (Ren et al. 1996; Schackwitz et al. 1996), the daf- 1 type I TGF- $\beta$ receptor (Georgi et al. 1990), the daf-4 type II TGF- $\beta$ receptor (Estevez et al. 1993), and the daf-14 SMAD (Inoue and Thomas 2000) genes also abolished sra-6 expression in the ASH and ASI neurons but not in the PVQ neurons (Table 1). daf-8 and daf-14 have been shown to act partly redundantly to regulate multiple processes (Inoue and Thomas 2000). Consistent with this, we found that although only $27 \%$ and $73 \%$ of $d a f-8$ and $d a f-14$ single mutants, respectively, showed a complete loss of sra-6 expression in the head (Table 1), $100 \%$ of daf-8; daf-14 double mutants failed to express sra-6 in both the ASH and ASI neurons $(\mathrm{n}=71)$. Interestingly, in all cases, expression of sra-6 was unaffected in L1 and early L2 stages, indicating that TGF- $\beta$ signaling is required for maintenance but not for initiation of sra-6 expression (Table 1).

The C. elegans genome is predicted to encode $>600$ chemosensory receptors of which the functions of only one have been defined (Troemel et al. 1995; Sengupta et al. 1996; Robertson 1998, 2000). The expression patterns of a fraction of these genes have been examined to date and shown to be expressed in small sets of chemosensory neurons (Troemel et al. 1995, 1997, 1999; Sengupta et al. 1996; Troemel 1999a; Peckol et al. 2001). To determine whether TGF- $\beta$ signaling is required for the expression of additional chemoreceptor genes, we examined the expression of receptor:: $g f p$ transgenes in daf-7 TGF- $\beta$ pathway mutants. Expression of three chemoreceptor genes was dramatically altered in the ASI chemosensory neurons, whereas the expression of additional receptors was largely unaffected or only weakly altered in other neuron types (Table 1). In wild-type animals cultured under favorable growth conditions, str-3 and srd-1::gfp fusion genes are expressed strongly in the ASI neurons (Peckol et al. 2001), whereas str-2::gfp is expressed strongly in one of the two AWC olfactory neurons and weakly in the two ASI neurons (Troemel et al. 1999; Peckol et al. 2001). In TGF- $\beta$ pathway mutants, expression of both str-3 and srd-1 was abolished, whereas expression of str-2 was strongly up-regulated in the ASI neurons. Expression of str-2 in the AWC neurons was not significantly affected (data not shown). Unlike sra-6 expression, the effects on str-3, srd-1, and str-2 expression were observed at all stages of postembryonic development. Consistent with previous reports (Vowels and Thomas 1994), we did not detect any gross defects in the ability of daf-7(e1372) or daf-4(m63) mutants to respond to multiple sensory stimuli, including a panel of volatile attractants and repellents (data not shown).

Two additional TGF- $\beta$ pathways are known to function in C. elegans. The DBL-1 pathway regulates body size (Suzuki et al. 1999), whereas the UNC-129 TGF- $\beta$ ligand is required for axon guidance and cell migration (Colavita et al. 1998). Mutations in dbl-1 or unc-129 did not affect chemosensory receptor gene expression (data not shown). These results indicate that DAF-7 but not UNC-129 or DBL-1 TGF- $\beta$ signaling is required for the

Table 1. Expression of a subset of chemoreceptor genes is altered in DAF-7 TGF- $\beta$ pathway mutants

\begin{tabular}{|c|c|c|c|c|c|c|c|}
\hline \multirow[b]{2}{*}{ Receptor $^{\mathrm{a}}$} & \multirow[b]{2}{*}{ Neuron } & \multicolumn{6}{|c|}{$\%$ animals expressing GFP } \\
\hline & & $\begin{array}{l}\text { Wild } \\
\text { type }\end{array}$ & daf $-7^{\mathrm{b}}$ & $d a f-1^{\mathrm{b}}$ & $d a f-4^{\mathrm{b}}$ & $d a f-8^{\mathrm{b}}$ & $d a f-14^{b}$ \\
\hline sra-6 larvae ${ }^{\mathrm{c}}$ & ASH & 100 & 100 & - & 100 & 100 & 100 \\
\hline sra-6 & ASH/ASI & $100^{\mathrm{d}}$ & $1^{\mathrm{d}}$ & $12^{\mathrm{d}}$ & $1^{\mathrm{d}}$ & $73^{\mathrm{d}}$ & $24^{\mathrm{d}}$ \\
\hline str-2 & $\mathrm{ASI}^{\mathrm{e}}$ & 0 & 100 & 100 & 100 & 59 & 95 \\
\hline str-3 & ASI & 100 & 0 & 1 & 0 & 0 & 0 \\
\hline srd-1 & ASI & 99 & 0 & 14 & 0 & - & - \\
\hline str-1 & AWB & 100 & 100 & - & 100 & 100 & 100 \\
\hline$o d r-10$ & AWA & 100 & 100 & - & - & 100 & - \\
\hline sre-1 & $\mathrm{ADL}$ & 98 & 100 & 97 & 100 & - & - \\
\hline $\operatorname{srg}-8$ & ASK & 87 & 98 & - & 99 & - & - \\
\hline T08G3.3 & $\mathrm{ADF}$ & 100 & 100 & - & - & 100 & 100 \\
\hline$s r g-13$ & PHA & 97 & 70 & - & 80 & - & - \\
\hline
\end{tabular}

Expression was observed at 400× magnification in all cases. $\mathrm{n}>70$ for each with the exception of $d a f-4 ; \operatorname{Ex}[\operatorname{srg}-13:: g f p]$ animals $(\mathrm{n}=58)$. - indicates not done.

aExpression was examined in strains containing integrated copies of receptor::gfp fusion genes or extrachromosomal arrays (srg-8 and srg-13) grown at $20^{\circ} \mathrm{C}$. For arrays, numbers shown are from the same array examined in wild-type and mutant animals.

${ }^{\mathrm{b}}$ Alleles used were daf-7(e1372), daf-1(m20), daf-4(m63), daf-8(e1393), and daf-14(m77).

${ }^{\mathrm{c}} \mathrm{L} 1 /$ early L2 larvae were examined. All other animals examined were young adults.

${ }^{\mathrm{d} I n}$ wild-type animals, $100 \%$ of the animals expressed GFP in a total of four cells (two ASH and two ASI). In daf-7 and daf-4 mutants, $1 \%$ expressed GFP in one neuron; in daf-1 mutants, $12 \%$ expressed GFP in one or two neurons; in daf- 8 mutants, $12 \%$ expressed GFP in one, $60 \%$ in two, and $1 \%$ in three neurons; in daf-14 mutants, $6 \%$ expressed GFP in one and $18 \%$ in two neurons.

eUnder normal growth conditions, str-2 is expressed weakly or undetectably in the ASI neurons. Expression is scored as bright GFP expression in both ASI neurons. 
correct expression of a subset of chemosensory receptor genes.

\section{Chemosensory receptor gene expression is} differentially regulated in wild type and in daf-7 TGF- $\beta$ pathway mutant dauer animals

Whereas wild-type animals enter into the dauer stage only on exposure to adverse environmental stimuli (Golden and Riddle 1984; Riddle and Albert 1997), daf-7 pathway mutants form dauers constitutively (Daf-c). The expression patterns of str-2 and srd-1 are altered in wild-type dauer animals (Peckol et al. 2001). To examine whether the expression of these chemoreceptor genes is altered similarly in TGF- $\beta$ pathway mutant dauers, we compared the expression of sra-6, str-2, str-3, and srd-1 in wild-type and daf-4 dauer animals (Table 2).

str-2 expression was up-regulated and srd-1 expression was down-regulated in the ASI neurons of both wild-type and daf-4 dauer animals (Table 2). However, while only $32 \%$ of wild-type dauers retained str-2 expression in a single AWC neuron, $\sim 73 \%$ of daf-4 dauers continued to express str-2 in an AWC neuron. We found that the expression of sra- 6 and str-3 was regulated differently in wild-type and daf-4 dauer animals. Although sra-6 expression is unaltered in wild-type dauers, sra-6 expression was abolished in the ASI, but not in the ASH neurons in daf-4 dauers (Table 2). Similarly, although str-3 is expressed at high levels in the ASI neurons in wild-type dauers, $98 \%$ of daf-4 dauer animals failed to express str-3 (Table 2). These results are summarized in Table 3.

Dauer entry is accompanied by remodeling of multiple tissues, including the nervous system (Albert and Riddle 1983; Riddle and Albert 1997). The ciliary endings of chemosensory neurons such as ASI retract, so that they are no longer exposed to the external environment via the amphid pore and consequently fail to uptake lipophilic dyes such as DiI (Albert and Riddle 1983; Herman and Hedgecock 1990; Peckol et al. 2001). This remodeling has been proposed to play a role in the altered expression of chemosensory receptor genes such as str-2 and str-3 in wild-type dauers (Peckol et al. 2001). The observed differences in chemoreceptor expression pat-

Table 2. Chemoreceptor genes are differentially expressed in wild-type and daf-4 dauers

\begin{tabular}{llcr}
\hline & \multicolumn{3}{c}{$\%$ dauers expressing GFP } \\
\cline { 2 - 4 } Receptor $^{\mathrm{a}}$ & Neuron & Wild type & daf-4 \\
\hline sra-6 & ASH & 100 & 98 \\
sra-6 & ASI & 97 & 2 \\
str-2 & ASI & 100 & 77 \\
str-3 & ASI & 100 & 2 \\
srd-1 & ASI & 10 & 6 \\
\hline
\end{tabular}

$\mathrm{n}>65$ in each case.

${ }^{a}$ Integrated receptor::gfp fusion genes were examined. Expression was scored as expression in one or both neurons.

${ }^{\mathrm{b}}$ Allele used was daf-4(m63). terns such as that of str-3 between wild-type and TGF- $\beta$ pathway mutant dauers could arise in part from the failure of the ASI neurons to remodel correctly in the absence of TGF- $\beta$ signaling or could reflect a direct requirement of TGF- $\beta$ signaling for gene expression. To address this issue, we examined the dye-filling ability of the ASI neurons in wild-type and daf-4 mutant dauers. We found that overall, similar numbers of wild-type and daf-4 mutant dauers failed to dye-fill the ASI neurons $196 \%$ wildtype versus $99 \%$ daf-4 dauers; $\mathrm{n}>95$ for each), suggesting that the ASI neurons are remodeled similarly. However, TGF- $\beta$ pathway mutant dauers recover more slowly than do wild-type dauers (Vowels and Thomas 1992), implying functional differences between these two types of dauers. These results suggest that TGF- $\beta$ signaling is required for the expression of a subset of chemosensory receptor genes in the ASI neurons in dauer animals.

daf-3 SMAD mutations suppress daf-7-induced but not pheromone-induced alterations in chemoreceptor gene expression patterns

The daf-7 TGF- $\beta$ pathway functions in developmental processes other than dauer formation. When allowed to bypass the dauer stage, daf-7 pathway mutant adults exhibit increased social behavior, decreased rates of egglaying, and a darkened intestine (Trent et al. 1983; Thomas et al. 1993). All phenotypes, including the Daf-c phenotype, are suppressed by mutations in the daf-3 SMAD and daf-5 genes (Vowels and Thomas 1992; Thomas et al. 1993). To determine whether mutations in daf-3 also suppress the receptor gene expression defects, we examined sra- 6 and str-2 expression in daf-7; daf-3 double mutants. As shown in Table 4, daf-3(mgDf90) fully suppressed the gene expression defects of str-2 and sra-6 in daf-7 mutants.

Exposure to high concentrations of pheromone results in down-regulation of daf-7 expression and subsequent dauer entry (Ren et al. 1996; Schackwitz et al. 1996). However, exposure to concentrations of pheromone that are insufficient to either grossly affect daf-7 expression or induce dauer entry has been shown to be sufficient to down-regulate str-3, srd-1, and str-2 expression in the ASI neurons (Peckol et al. 2001). We found that pheromone also down-regulates sra-6 expression in the ASI but not the ASH neurons (Fig. 2A; Table 3; data not shown). To determine whether pheromone-mediated receptor regulation functions via down-regulation of TGF- $\beta$ signaling, we examined receptor expression in daf-3 mutants on the addition of low levels of pheromone. Mutations in daf-3 failed to suppress the pheromone-mediated down-regulation of str-3, str-2, or sra-6 expression in the ASI neurons (Fig. 2A-C). This suggests that pheromone, at subdauer-inducing concentrations, acts via a TGF- $\beta$-independent pathway to regulate receptor expression. However, because dauer pheromone is a complex mixture of fatty acids, we cannot exclude the possibility that different components of pheromone are active at different concentrations. 
Table 3. Summary of expression patterns of chemoreceptor genes

\begin{tabular}{|c|c|c|c|c|c|c|}
\hline \multirow[b]{2}{*}{ Receptor } & \multirow[b]{2}{*}{ Neuron } & \multicolumn{5}{|c|}{ GFP expression under various conditions } \\
\hline & & $\begin{array}{c}\text { WT } \\
\text { adults }\end{array}$ & $\begin{array}{c}\text { daf-4 } \\
\text { adults }\end{array}$ & $\begin{array}{c}\text { WT } \\
\text { dauers }\end{array}$ & $\begin{array}{c}\text { daf-4 } \\
\text { dauers }\end{array}$ & $\begin{array}{c}+ \\
\text { pheromone }\end{array}$ \\
\hline sra-6 & ASH & ON & OFF & ON & ON & ON \\
\hline sra-6 & ASI & $\mathrm{ON}$ & OFF & $\mathrm{ON}$ & OFF & OFF \\
\hline str-2 & ASI & weak/OFF & $\mathrm{ON}$ & $\mathrm{ON}$ & $\mathrm{ON}$ & OFF \\
\hline str-3 & ASI & ON & OFF & ON & OFF & OFF \\
\hline srd-1 & ASI & $\mathrm{ON}$ & OFF & OFF & OFF & $\mathrm{OFF}^{\mathrm{a}}$ \\
\hline
\end{tabular}

${ }^{\mathrm{a}}$ Data from Peckol et al. 2001.

Dauer entry is regulated in parallel by the $d a f-7$ TGF- $\beta$ and the daf-2 insulin signaling pathways (Gottlieb and Ruvkun 1994; Riddle and Albert 1997). We determined whether insulin signaling also plays a role in chemosensory receptor gene expression. We found that expression of chemoreceptor genes examined was unaltered in daf-2 mutants (Table 4; data not shown), indicating that expression of these chemoreceptor genes does not require insulin signaling via DAF-2.

The daf-12 nuclear hormone receptor gene is required for chemoreceptor regulation in the ASI but not the ASH neurons

In one model, the observed defects in chemoreceptor gene expression could arise solely as a consequence of defects in TGF- $\beta$ signaling in the context of dauer formation. Alternatively, these defects could reflect a requirement for TGF- $\beta$ signaling independent of its role in the dauer pathway. The daf-7- and daf-2-regulated pathways converge at the daf-12 nuclear hormone receptor gene to regulate dauer formation. Mutations in daf-12 suppress the Daf-c but not the adult-specific phenotypes of daf-7 pathway mutants (Thomas et al. 1993; Riddle and Albert 1997). Thus, the adult-specific phenotypes are regulated by TGF- $\beta$ signaling via a daf-12-independent and hence a dauer pathway-independent mechanism. We examined receptor gene expression in daf-7; daf-12 double mutants to determine whether mutations in $d a f$ 12 suppress the gene expression defects of TGF- $\beta$ pathway mutants.

Unexpectedly, we found that mutations in daf-12 alone affected chemoreceptor gene expression in the ASI neurons. Expression of sra-6 was strongly down-regulated, and expression of str-2 was up-regulated in the ASI neurons and was unaffected in the ASH and AWC neurons in daf-12(rh61rh411) null mutants (Table 4; data not shown), suggesting that DAF-12 function is required for the correct expression of these receptors only in the ASI neurons. Interestingly, str-2 expression in the ASI neurons of daf-7; daf-12 double mutants was more variable than that of either daf-7 or daf-12 mutants alone. It is possible that in the absence of both TGF- $\beta$ signaling and daf-12 function, additional mechanisms for str-2 regulation in the ASI neurons are revealed. Moreover, daf-12(rh61rh411) failed to suppress the sra-6 expression defect in the ASH neurons of daf-7 mutants (Table 4), suggesting that the requirement for TGF- $\beta$ signaling in sra-6 regulation in the ASH neurons is independent of its role in dauer formation. These results imply that the TGF- $\beta$ pathway may function through or in parallel to daf-12 to regulate chemoreceptor gene expression in the ASI but not in the ASH neurons, thus revealing cellspecific mechanisms of chemoreceptor gene regulation.

DAF-4 function is required both early and late in development to regulate chemoreceptor gene expression

daf-7 mRNA levels have been shown to peak in the L1 larval stage, and are down-regulated in subsequent stages (Ren et al. 1996). Because TGF- $\beta$ pathway mutants exhibit a number of adult phenotypes, it is possible that TGF- $\beta$ signaling early in development is sufficient to regulate adult stage-specific characteristics. Alternatively, TGF- $\beta$ signaling may be required at multiple developmental stages, including the adult stage. To distinguish between these possibilities, we examined the temporal requirement for DAF-4 type II receptor function in the regulation of sra- 6 expression.

Animals carrying the daf-4(m592) mutation are temperature-sensitive: When grown at the permissive temperature of $15^{\circ} \mathrm{C}$, they exhibit wild-type body size and male tail morphology (Baird and Ellazar 1999). To determine when DAF-4 function is required for receptor gene regulation, we grew daf-4(m592) animals expressing the sra-6::gfp fusion gene at $15^{\circ} \mathrm{C}$ or $25^{\circ} \mathrm{C}$, and shifted animals between these temperatures at different developmental stages. Adult animals were then examined for their sra-6 expression pattern $24 \mathrm{~h}$ after the final molt. Animals shifted from the permissive to restrictive temperature prior to late L2 stages exhibited a mutant sra- 6 phenotype as adults (Fig. 3A). However, animals shifted at late L2 stages or later exhibited the wild-type pattern of sra-6 expression. In converse downshift experiments, we found that animals shifted to the permissive temperature prior to the L3 stage exhibited the wild-type expression pattern as adults (Fig. 3B). These experiments suggest that DAF-4 function is required during the late L2/early L3 stage to regulate sra-6 expression.

To examine whether DAF-4 function is also required in the adult to maintain receptor gene expression, we 
Nolan et al.

Table 4. daf-3 suppresses the expression defects of chemoreceptor genes in daf-7 mutants

\begin{tabular}{|c|c|c|c|c|c|c|c|}
\hline \multirow[b]{2}{*}{ Receptor } & \multirow[b]{2}{*}{ Neuron } & \multicolumn{6}{|c|}{$\%$ mutants expressing the wild-type pattern ${ }^{a}$} \\
\hline & & $d a f-7^{\mathrm{b}}$ & $d a f-3^{\mathrm{b}}$ & $d a f-12^{\mathrm{b}}$ & $d a f-2^{\mathrm{b}}$ & $\begin{array}{l}\text { daf-7; } \\
\text { daf- } 3^{\text {b }}\end{array}$ & $\begin{array}{c}\text { daf-7; } \\
\text { daf-12, }\end{array}$ \\
\hline \multirow[t]{2}{*}{ sra-6 } & ASH & 0 & 100 & 100 & 99 & 100 & 6 \\
\hline & ASI & 0 & 100 & 0 & 99 & 100 & 0 \\
\hline str-2 & ASI & 0 & 100 & 0 & 95 & 100 & $45^{\mathrm{d}}$ \\
\hline
\end{tabular}

$\mathrm{n}>95$ for each.

${ }^{\text {a} W i l d-t y p e ~ s r a-6 ~ e x p r e s s i o n ~ i s ~ d e f i n e d ~ a s ~ G F P ~ e x p r e s s i o n ~ i n ~ t w o ~ A S H ~ o r ~ A S I ~ n e u r o n s . ~ W i l d-t y p e ~ s t r-2 ~ e x p r e s s i o n ~ i s ~ d e f i n e d ~ a s ~ w e a k ~ o r ~}$ undetectable GFP expression in both ASI neurons.

${ }^{\mathrm{b}}$ Alleles used were daf-7(e1372), daf-3(mgDf90), daf-12(rh61rh411), and daf-2(e1370).

${ }^{\mathrm{c}}$ daf-12(rh61rh411) fully suppressed the Daf-c phenotype, but not the small body size or Egl phenotypes of daf-7 mutants (data not shown).

${ }^{\mathrm{d}}$ The intensity of GFP expression and the number of animals expressing GFP in the ASI neurons was variable both within and between independent experiments.

temperature shifted daf-4(m592) mutant adult animals for various lengths of time and examined sra-6 expression. When daf-4(m592) mutant animals were grown at $15^{\circ} \mathrm{C}$ until $24 \mathrm{~h}$ after the final molt, and then shifted to $25^{\circ} \mathrm{C}$ for $72 \mathrm{~h}$, we observed reduced levels of GFP expression with further reduction in expression after $96 \mathrm{~h}$ (Fig. 3C). Because GFP perdures (Li et al. 1998; Corish and Tyler-Smith 1999), it is possible that endogenous sra-6
$\mathbf{A}$

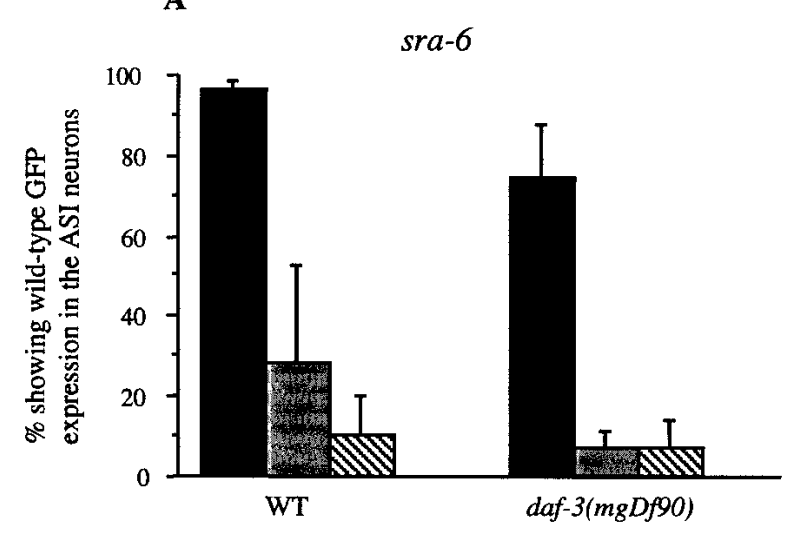

$\mathbf{C}$

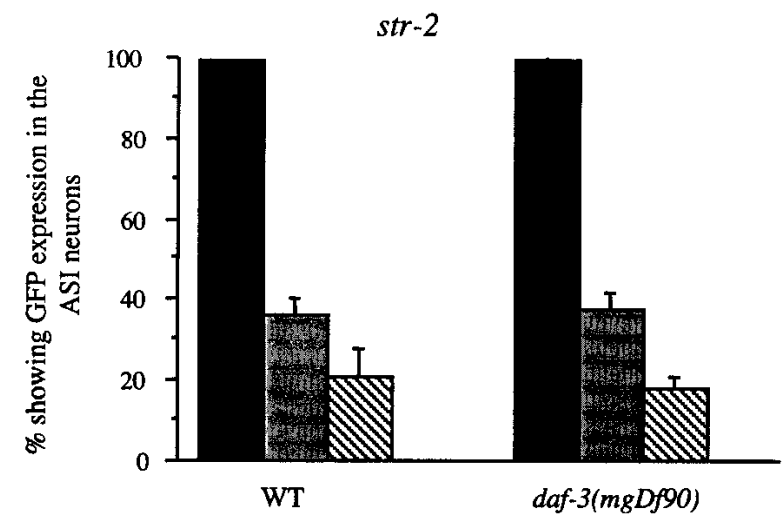

B

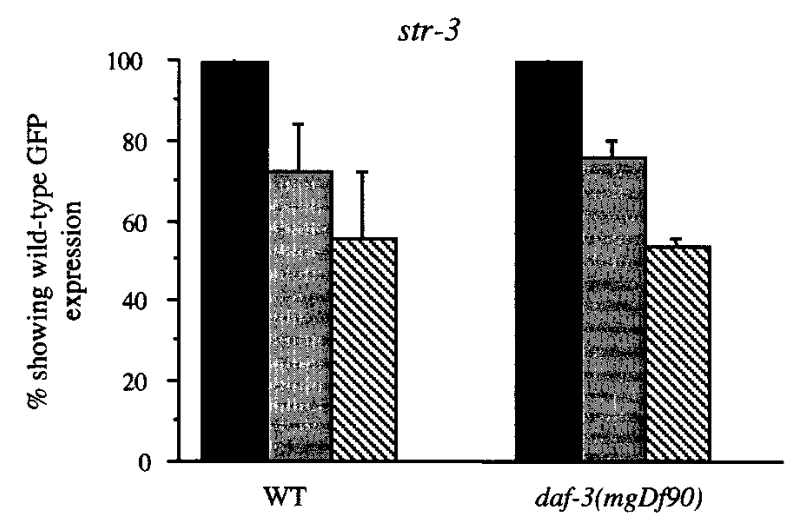

Figure 2. daf-3(mgDf90) fails to suppress the pheromone-mediated alteration of chemoreceptor expression in the ASI neurons. Shown are the percentages of wild-type or daf-3(mgDf90) animals expressing sra-6 $(A)$, str-3 $(B)$, or str-2 $(C)$ in both ASI neurons on exposure to $0 \mu \mathrm{L}$ (solid bars), $10 \mu \mathrm{L}$ (shaded bars), or $20 \mu \mathrm{L}$ (hatched bars) of pheromone. str-2 is expressed weakly in the ASI neurons and is further reduced on pheromone addition. Pheromone did not induce dauer formation at these concentrations. Larval-stage animals were examined $24 \mathrm{~h}$ after hatching from eggs laid on plates containing the indicated concentrations of pheromone. Expression in adult animals examined $48 \mathrm{~h}$ after hatching on pheromone were also similar in wild-type and daf-3 mutants (data not shown). Data shown are the mean of at least three independent experiments, and error bars represent S.E.M.; $\mathrm{n}>50$ for each column. 

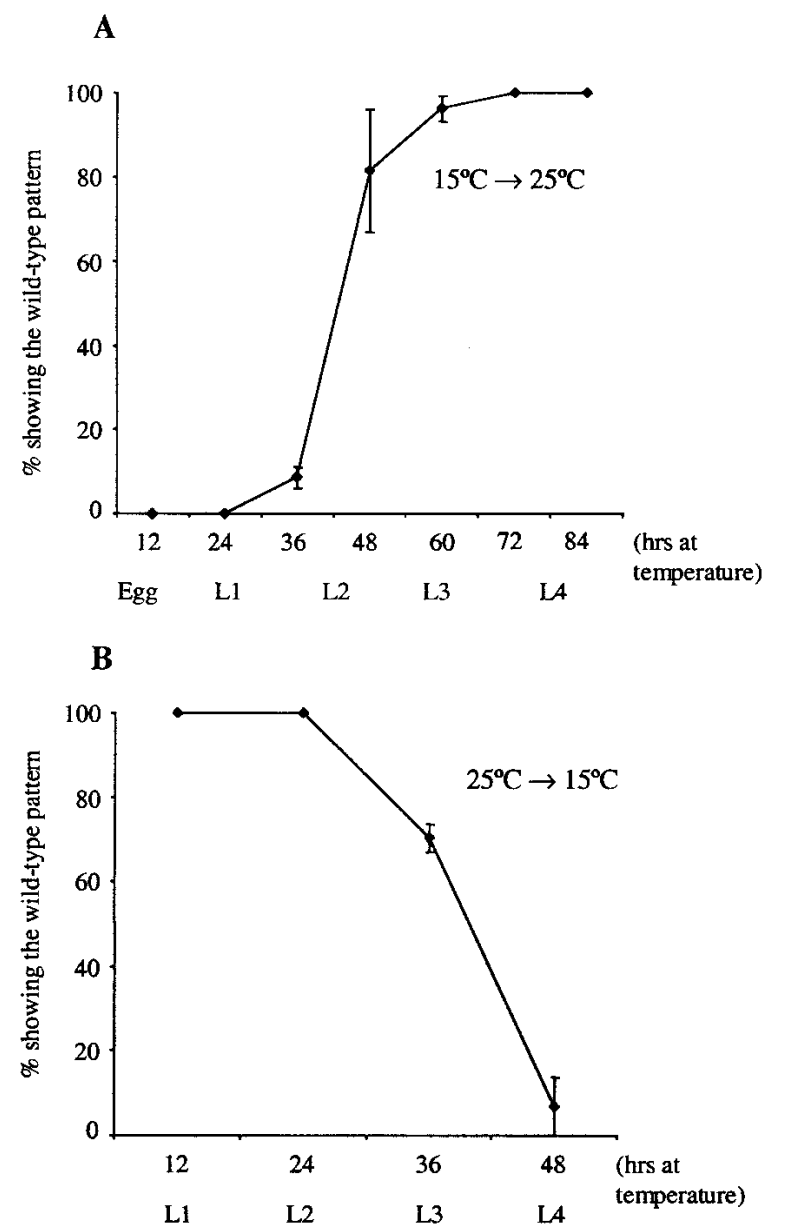

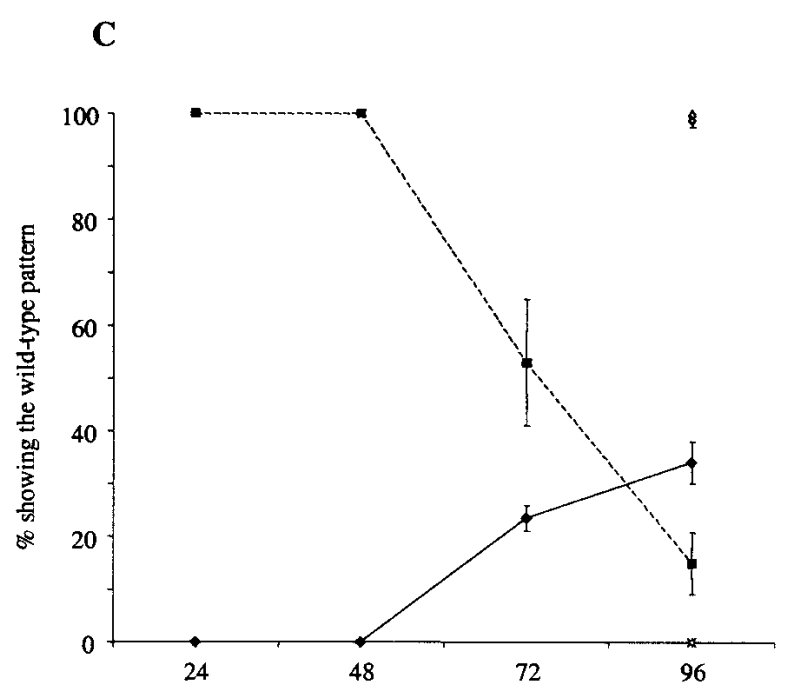

Hours after shift

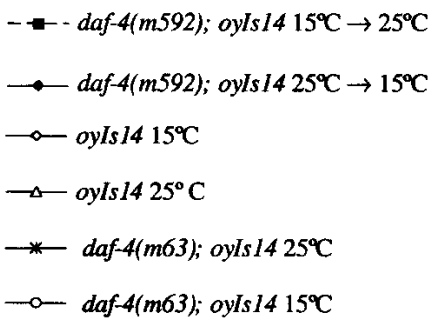

Figure 3. DAF-4 function is required in the larval and adult stages for sra-6 expression. $(A, B)$ daf-4(m592); oyIs14 animals were raised at $15^{\circ} \mathrm{C}(A)$ or $25^{\circ} \mathrm{C}(B)$ and shifted to the restrictive $\left(25^{\circ} \mathrm{C}\right)$ or permissive $\left(15^{\circ} \mathrm{C}\right)$ temperatures, respectively, at 12 -h intervals. The developmental stage at the time of shift is indicated. The sra-6 expression pattern was examined in young adult animals $24 \mathrm{~h}$ after the L4/adult transition. Wild-type expression was defined as expression in at least three neurons in the head. Data shown are from at least three independent experiments. A total of $>95$ animals were examined at each point for the upshift experiments $(A)_{;}>70$ animals were examined per time point for the downshift experiments $(B) .(C)$ daf-4(m592); oyIs14 animals were grown at either the permissive or restrictive temperatures until the adult stage. Adult animals were then temperature-shifted for the indicated times, and the sra- 6 expression pattern was examined. Wild-type expression was defined as above. Data shown are from at least two independent experiments with $>70$ animals examined at each time point.

expression is reduced earlier on temperature shift from $15^{\circ} \mathrm{C}$ to $25^{\circ} \mathrm{C}$. However, complete restoration of GFP expression to wild-type levels was not observed in animals shifted as adults from $25^{\circ} \mathrm{C}$ to $15^{\circ} \mathrm{C}$, even after $96 \mathrm{~h}$. Wild-type and daf-4(m63) mutant animals grown continuously at either $15^{\circ} \mathrm{C}$ or $25^{\circ} \mathrm{C}$ retained their expected expression patterns. These results indicate that DAF-4 function is required both before and during the adult stage to maintain sra-6 expression.

The ASI neurons are required in the larval but not in the adult stages to regulate sra- 6 expression

Because neither daf-7 mRNA nor an ASI-expressed DAF$7::$ GFP fusion protein is detected in adult animals (Ren et al. 1996; Schackwitz et al. 1996), it is possible that DAF-4 may be activated by a different TGF- $\beta$ ligand or via a novel mechanism in adults. To determine whether the ASI neurons are also the source of a DAF-4 ligand in adult animals, we killed both the ASI neurons in L1 larvae and adult wild-type animals and examined sra-6::gfp expression in the ASH neurons. Killing the ASI neurons in L1 larvae resulted in the expected loss of sra-6 expression in the ASH neurons of young adult animals (Table 5), whereas killing both the ASI neurons in adult animals did not significantly affect sra-6 expression in the ASH neurons, even after $4 \mathrm{~d}$. These results suggest that DAF-4-mediated maintenance of sra- 6 expression in adult animals may require a ligand secreted from a cell(s) in addition to or other than the ASI neurons. However, we are unable to exclude the possibility that ablation of the ASI nuclei in adult animals does not lead to a complete elimination of ASI function (Chalfie and Sulston 1981). 
Table 5. The ASI neurons are required in larval but not in adult stages to maintain sra-6 gene expression in the ASH neurons

\begin{tabular}{lc}
\hline $\begin{array}{l}\text { Developmental stage } \\
\text { of ASI ablation }\end{array}$ & $\begin{array}{c}\text { \% expressing sra-6::gfp in } \\
\text { the ASH neurons }(\mathrm{n})^{\mathrm{a}}\end{array}$ \\
\hline L1 & $6.6(15)$ \\
L1 mock ablation & $100(25)$ \\
Young adult & $81(16)$ \\
Young adult mock ablation & $100(23)$ \\
\hline
\end{tabular}

All experiments were carried out in wild-type animals carrying integrated copies of the sra-6::gfp (oyIs14) fusion gene. Animals were grown at $25^{\circ} \mathrm{C}$ postablation.

GFP expression in the ASH neurons was examined $4 \mathrm{~d}$ postablation.

${ }^{\mathrm{a}} \mathrm{n}=$ number of animals in which both ASI neurons were killed.

The DAF-4 type II TGF- $\beta$ receptor acts cell autonomously to regulate chemosensory receptor gene expression and non-cell-autonomously to regulate dauer formation

In contrast to the restricted expression pattern of daf-7, the daf-1 and daf-4 receptor genes and the daf-14 SMAD gene are expressed broadly in many tissue types, including the nervous system (Georgi et al. 1990; Estevez et al. 1993; Inoue and Thomas 2000). DAF-4 functions noncell-autonomously in the nervous system to regulate dauer formation (Inoue and Thomas 2000), but specific sites of action within the nervous system have not been identified.

To investigate where DAF-4 acts to regulate chemosensory receptor expression, we expressed a daf-4 cDNA by using the odr-4 and osm-10 promoters and determined whether sra- 6 and str-2 expression was rescued in daf- 4 mutants. The odr- 4 promoter drives expression primarily in 10 pairs of chemosensory neurons in the head and two pairs of chemosensory neurons in the tail (Dwyer et al. 1998), whereas the osm-10 promoter drives expression strongly in the ASH and weakly in the ASI neurons, as well as in the two phasmid neurons in the tail (Hart et al. 1999). We found that odr-4::daf-4 expression was sufficient to fully rescue the sra- 6 and weakly rescue the str-2 expression defects (Table 6). However, expression of daf-4 under the myo-3 promoter, which drives expression in body wall muscles (Hsieh et al. 1999), did not restore sra-6 expression. The Daf-c phenotype of daf-4 mutants was also weakly rescued by expression of daf-4 under the odr-4 promoter (Table 6), suggesting that DAF-4 may act partly in the chemosensory neurons to regulate dauer formation.

Expression of daf-4 under the osm-10 promoter also rescued the sra- 6 gene expression defects in the ASH neurons, whereas sra- 6 expression defects in the ASI neurons were only weakly rescued (Table 6). Although these results are likely due to the stronger expression driven by the osm-10 promoter in the ASH compared with the ASI neurons (Hart et al. 1999), it is also possible that the low levels of daf-4 expression in the ASI neurons in these animals is sufficient to regulate sra- 6 expression in the ASH neurons. To address this possibility, we killed the ASI neurons in adult daf-4 transgenic animals expressing osm-10::daf-4 and examined sra-6 expression in the ASH neurons. We found that killing both the ASI neurons did not significantly affect maintenance of sra-6 expression in the ASH neurons (Table 6), suggesting that DAF-4 functions cell-autonomously to regulate sra-6 expression. In similar experiments, we found that the DAF-3 SMAD protein may also act cell-autonomously to antagonize the daf-7 TGF- $\beta$ pathway in chemoreceptor gene regulation and non-cell-autonomously in the nervous system to regulate dauer formation (Supplementary Table 1).

\section{Discussion}

\section{Multiple mechanisms regulate the expression of individual chemoreceptor genes}

We have shown that the DAF-7 TGF- $\beta$ pathway regulates the expression of all known chemoreceptor genes in

Table 6. daf-4 acts cell-autonomously to regulate chemoreceptor gene expression and non-cell-autonomously to regulate dauer formation

\begin{tabular}{lccc}
\hline & \multicolumn{2}{c}{$\%$ animals expressing } & \\
\cline { 2 - 3 } Strain & sra-6::gfp & str-2::gfp & formed $^{\mathrm{b}}$ \\
\hline WT & 100 & 0 & 0 \\
daf-4(m63) & $4^{\mathrm{c}}$ & 100 & 100 \\
daf-4(m63); Ex[odr-4::daf-4] & $93^{\mathrm{d}}$ & 23 & 76 \\
daf-4(m63); Ex[osm-10::daf-4] & $91^{\mathrm{e}}$ & - & 85 \\
daf-4(m63); Ex[myo-3::daf-4] & 3 & - & - \\
daf-4(m63); Ex[osm-10::daf-4] & 81 & - & - \\
ASI killed (adults) & & & \\
daf-4(m63); Ex[osm-10::daf-4] $^{\mathrm{f}}$ mock ablated (adults) & & & \\
\hline
\end{tabular}

All strains contain the pRF4 coinjection marker with the exception of ASI-killed and mock-ablated animals which contain the unc-122::gfp coinjection marker (Miyabayashi et al. 1999). Data shown are from two independent lines, each of which showed similar levels of rescue. $\mathrm{n}>95$ for each.

- indicates not done.

aExpression was scored as sra-6::gfp expression in one to four neurons in the head. In ASI-killed animals, expression was scored as expression in both ASH neurons. Expression was scored as weak str-2::gfp expression in one or two ASI neurons. ${ }^{b}$ Dauer formation was examined at $25.5^{\circ} \mathrm{C}$ as described previously (Lanjuin and Sengupta 2002).

${ }^{c} 3.1 \%$ of animals expressed GFP in one cell, and $1 \%$ expressed it in two cells.

$\mathrm{d}_{2} \%$ expressed GFP in one cell, $32 \%$ expressed GFP in two cells, $14 \%$ expressed GFP in three cells, and $45 \%$ expressed GFP in four cells.

${ }^{\mathrm{e}} 10 \%$ expressed GFP in one cell, $52 \%$ expressed GFP in two cells, $12 \%$ expressed GFP in three cells, and $17 \%$ expressed GFP in four cells. In animals in which GFP was expressed in two cells, both cells were identified as ASH by dye-filling (100\%, $\mathrm{n}=31$ ).

${ }^{\mathrm{f}}$ Data shown for ASI-killed animals are from one line; $\mathrm{n}=11$ for ASI-killed animals; $\mathrm{n}=22$ for mock ablated animals. ASI neurons were killed in young adult animals, and GFP expression was scored after $4 \mathrm{~d}$ at $25^{\circ} \mathrm{C}$. 
the ASI neurons and of the sra- 6 chemoreceptor gene in the ASH neurons, as determined by examining changes in the expression of receptor:: gfp transgenes. Chemosensory neurons such as ASI and ASH are born embryonically (Sulston et al. 1983), and the expression of chemosensory signal transduction genes can be detected by late embryonic stages (Troemel et al. 1999; P. Sengupta, unpubl.). Transcription factors required for the developmental specification of individual sensory neuron types have been described (Sengupta et al. 1994; Baran et al. 1999; Sagasti et al. 1999; Sarafi-Reinach and Sengupta 2000; Pierce-Shimomura et al. 2001; Sarafi-Reinach et al. 2001; Satterlee et al. 2001). Mutations in these factors result in the altered expression of most, if not all, sensory neuron-specific genes encoding chemoreceptors, channels, and guanylyl cyclases, resulting in strong behavioral phenotypes (Sengupta et al. 1994; Baran et al. 1999; Sagasti et al. 1999; Pierce-Shimomura et al. 2001; Satterlee et al. 2001). In contrast, daf-7 signaling pathway mutants exhibit wild-type responses to known odorants, suggesting that although the expression of a subset of chemoreceptors is altered, the expression of other receptors and downstream signal transduction components is largely unaffected. In previous work, we described the Ser/Thr kinase gene kin-29, mutations in which also result in altered expression of a partly overlapping group of chemoreceptors, but not of additional signaling components (Lanjuin and Sengupta 2002). These results imply that in addition to developmentally hard-wired mechanisms, individual chemoreceptor genes are subject to additional modes of regulation.

The expression of chemosensory receptors in the ASI neurons in particular appears to be subject to multiple modes of regulation (Fig. 4). Non-dauer-inducing levels of pheromone repress the expression of all ASI-expressed receptors (Peckol et al. 2001; the present study). In addition, srd-1 expression in the ASI neurons requires neuronal activity (Peckol et al. 2001). In addition to these regulatory mechanisms, we find that TGF- $\beta$ signaling regulates receptor expression in the ASI neurons. DAF-7 signaling is required to promote the expression of str-3, sra-6, and srd-1 and to repress the expression of str- 2 in the ASI neurons. We suggest that during reproductive growth in wild-type animals, the balance of DAF-7 signaling and levels of pheromone regulates receptor expression in the ASI neurons. Very low levels of pheromone may be sufficient to down-regulate str-2 expression in the ASI neurons, without affecting the expression of additional receptors (Peckol et al. 2001). Higher, yet non-dauer-inducing levels of pheromone repress the expression of all ASI-expressed receptors via a DAF-7-independent pathway. It is interesting to note that the pheromone-mediated repression of ASI-expressed chemoreceptor genes has been observed at all developmental stages (Peckol et al. 2001; the present study). Moreover, pheromone has also been shown to modulate the responses of adult animals to volatile anesthetics via a DAF-7-independent pathway (Van Swinderen et al. 2002).

On entry into the dauer stage, withdrawal of the ASI cilia from the amphid pore results in derepression from
A $\underline{\text { ASI }}$

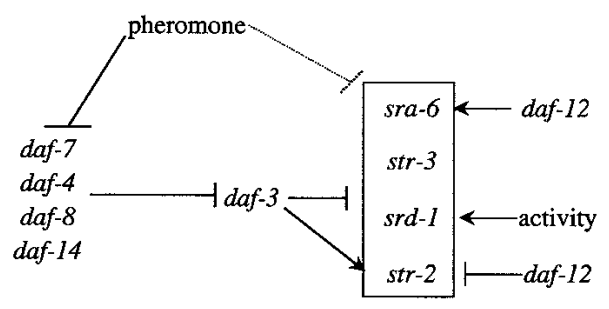

B $\underline{\text { ASH }}$

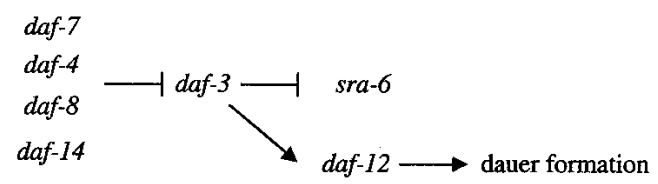

Figure 4. Model for regulation of chemoreceptor expression. $(A)$ In the ASI neurons, DAF-7 TGF- $\beta$ signaling maintains the expression of sra-6, promotes the expression of str-3 and srd-1, and represses expression of str-2. High levels of dauer pheromone repress daf-7 expression and promote dauer entry. Subdauer-inducing concentrations of pheromone (indicated by the dashed line) repress the expression of sra-6, str-3, str-2, and presumably srd-1 (in box) via a DAF-7-independent pathway. In addition, the DAF-12 nuclear hormone receptor is required to promote $s r a-6$ expression and to repress $s t r-2$ expression in the ASI neurons. srd-1 expression also requires neuronal activity (Peckol et al. 2001). (B) In the ASH neurons, DAF-7 signaling via the DAF-3 inhibitory SMAD but not DAF-12 maintains sra- 6 expression.

the effects of pheromone, resulting in restoration of expression of str-2, str-3, and sra-6. However, lack of neuronal activity prevents expression of srd-1 (Peckol et al. 2001). DAF-7 signaling may also be required to regulate receptor expression in the ASI neurons during the dauer stage. Alternatively, altered chemoreceptor expression in the dauer stage in TGF- $\beta$ pathway mutants may simply reflect a failure to activate or repress receptor expression in earlier larval stages. Thus, at least three pathways of pheromone, TGF- $\beta$ signaling, and neuronal activity regulate the expression of individual chemoreceptors in the ASI neurons. Curiously, to date, only ASI-expressed receptors have been shown to be regulated by pheromone, suggesting that modulation of ASI function by environmental conditions may be critical for behavioral or developmental plasticity.

Although sra-6 expression in the ASH neurons is also regulated by the $d a f-7$ pathway, receptor expression in the ASI and ASH neurons appear to be regulated by distinct mechanisms (Fig. 4; Table 3). First, sra-6 expression in the ASH neurons is unaffected by pheromone. Second, although the expression of both sra-6 and str-2 in the ASI neurons is also regulated by daf-12, sra-6 expression in the ASH neurons is unaffected in $d a f-12$ null mutants. Third, TGF- $\beta$ signaling appears to be required for sra- 6 expression in the ASI, but not the ASH, neurons in dauer animals. The differential regulation of receptor genes in individual neuron types under different environmental and developmental conditions may allow animals to more precisely modulate their sensory behaviors. 


\section{The DAF-4-mediated TGF- $\beta$ pathway functions in adult animals to maintain sra-6 expression}

We have defined a new role for the daf-7 TGF- $\beta$ pathway in maintaining sra-6 expression in adult animals. Mutations in components of this signaling pathway result in adult-specific phenotypes, including increased social behavior and defective egg-laying (Trent et al. 1983; Thomas et al. 1993). Although these phenotypes could result solely from a lack of TGF- $\beta$ signaling in larval stages, we have shown that in addition to being required during the late L2/early L3 stage, the function of the DAF-4 type II TGF- $\beta$ receptor is also required in the adult to maintain sra- 6 expression in the ASI and ASH neurons. Because this regulation occurs at developmental stages after the stage at which animals make the decision to form dauers, this result indicates that the regulation of receptor expression by the daf-7 pathway is independent of the function of this pathway in dauer formation. This hypothesis is further supported by our finding that mutations in daf-12 do not suppress the ASH-specific sra-6 expression defects of daf-7 pathway mutants.

The finding that DAF-4 signaling is required in adults is unexpected because it has been previously shown that daf-7 mRNA levels peak in the L1 larval stage and are severely reduced in the dauer and later developmental stages (Ren et al. 1996). A daf-7::gfp fusion gene appears to be expressed primarily in the ASI neurons in larvae (Ren et al. 1996; Schackwitz et al. 1996), and we have shown that killing the ASI neurons in L1 animals results in a loss of sra-6 expression in the ASH neurons in adults. However, the ASI neurons appear not to be the sole source of ligand for maintenance of sra-6 expression in adult animals. It is possible that daf-7 is expressed at low levels in the adult in additional neurons. Alternatively, DAF- 4 could be activated by a distinct TGF- $\beta$ ligand. The DBL-1 TGF- $\beta$ ligand also acts through DAF-4 to regulate body size (Suzuki et al. 1999). However, mutations in dbl-1 or unc-129 do not affect chemoreceptor expression. At least one additional TGF- $\beta$-like ligand is predicted to be encoded by the C. elegans genome (Ruvkun and Hobert 1998). It is possible that DAF-4 could be activated by other ligands to regulate receptor expression in the adult.

\section{Regulation of chemosensory receptor expression may contribute to sensory plasticity}

The combinatorial control of chemoreceptor gene expression by multiple pathways may enable the expression of these genes to be finely adjusted as in a rheostat. Different subsets of receptors in particular neuron types may be regulated by different developmental and environmental signals. By integrating information acquired via distinct pathways to alter chemoreceptor gene expression, animals can exhibit the responses most optimal for development and survival. Other organisms also modulate chemosensory receptor expression in response to developmental or environmental cues. Drosophila exhibits distinct chemosensory responses and expresses different sets of chemosensory receptor genes in the larval and adult stages (Dubin et al. 1995; Shaver et al. 1998; Scott et al. 2001). Olfactory receptors are also expressed in a temporally regulated manner in zebrafish, Xenopus laevis, and Drosophila during development and may contribute to stage-specific sensory behaviors (Barth et al. 1996; Clyne et al. 1999; Mezler et al. 1999|. The expression of an olfactory receptor has been shown to be down-regulated after a blood meal in the mosquito Anopheles gambiae and may be causal to their reduced responses to human odors during this period (Fox et al. 2001). Thus, modulation of receptor expression may be a general mechanism contributing to chemosensory plasticity.

\section{Materials and methods}

\section{Strains}

Worms were grown by using standard methods (Brenner 1974); all animals were grown at least one generation poststarvation at $20^{\circ} \mathrm{C}$ prior to analysis unless otherwise noted. Strains were obtained from the Caenorhabditis Genetics Center with the exception of daf-4(m592), which was kindly provided by D. Riddle (University of Missouri-Columbia, Columbia, MS; Baird and Ellazar 1999). Strains containing integrated transgenes were obtained as indicated previously (Lanjuin and Sengupta 2002). Double and triple mutant strains were constructed by using standard methods and confirmed by complementation tests or by sequencing. Details of strain construction are available on request.

\section{Isolation of daf-8(oy8)}

A strain carrying integrated copies of sra-6::gfp (oyIs14) was mutagenized with EMS by using standard protocols. oy8 was identified in a screen of $\sim 13,000$ haploid genomes for alterations in sra-6::gfp expression by using a dissection microscope equipped with epifluorescence. oy8 was mapped to LG I and fine-mapped with respect to deficiencies, genetic markers, and polymorphisms. oy8 fails to complement daf-8(e1393) for the sra-6 expression defect and the Daf-c phenotype.

\section{Expression constructs and generation of transgenic animals}

daf-4 expression constructs were generated by fusing odr-4 (Dwyer et al. 1998), osm-10 (Hart et al. 1999), or myo-3 (Hsieh et al. 1999) promoters to a daf-4 cDNA kindly provided by J. Thomas (University of Washington; Seattle, WA; Inoue and Thomas 2000). Amplified products were sequenced to confirm the absence of errors. Transgenic animals were generated by using the dominant co-injection markers pRF4 rol-6(su006) or unc-122::gfp at $100 \mathrm{ng} / \mathrm{\mu L}$. All other plasmids were injected at $30 \mathrm{ng} / \mu \mathrm{L}$.

\section{Laser ablations}

ASI neurons in oyIs14 animals were identified by DiI filling prior to ablation. Ablations were carried out using a Micropoint laser system (Photonic Instruments) essentially as previously described (Avery and Horvitz 1989). Successful killing of ASI was determined $24 \mathrm{~h}$ postablation by confirming loss of oyIs 14 expression in the ASI neurons. In daf-4(m63); oyIs14 (Ex osm10::daf-4, unc-122::gfp) animals, the ASI neurons were killed 
only in those transgenic animals in which the expression of oyIs14 was restored in both the ASH and ASI neurons. All phenotypes were scored $4 \mathrm{~d}$ postablation at $25^{\circ} \mathrm{C}$. Mock controls were treated identically to ablated animals, except that no ablations were performed.

\section{Dauer assays}

Adults were allowed to lay $\sim 50$ to 75 eggs $/ 6-\mathrm{cm}$ worm growth plate at room temperature. Parents were then removed, and the plates were shifted to $25.5^{\circ} \mathrm{C}$. The number of dauer and nondauer animals was counted $48 \mathrm{~h}$ later. Data presented in tables are from a single experiment, with all strains assayed in parallel. Experiments were repeated a minimum of three times on independent days, and the data showed similar relative differences. For pheromone exposure experiments, animals were allowed to lay eggs for $2 \mathrm{~h}$ at room temperature on dauer agar plates containing pheromone (Vowels and Thomas 1994), parents were removed, and the plates were placed at $25.5^{\circ} \mathrm{C}$. GFP expression was scored in larvae $24 \mathrm{~h}$ later and in young adults after $48 \mathrm{~h}$. No dauers were formed under these conditions; however, $\sim 38 \%$ to $48 \%$ of kin-29(oy39) mutants formed dauers in the presence of 10 or $20 \mu \mathrm{L}$ pheromone (Lanjuin and Sengupta 2002).

\section{Temperature-shift experiments}

daf-4(m592); oyIs14 were grown for at least one generation at either $15^{\circ} \mathrm{C}$ or $25^{\circ} \mathrm{C}$ prior to the experiment. Adults were allowed to lay eggs for $2-4 \mathrm{~h}$ at room temperature, the parents were removed, and the plates were placed at either $15^{\circ}$ or $25^{\circ} \mathrm{C}$. Plates were then shifted to the restrictive $\left(25^{\circ} \mathrm{C}\right)$ or permissive $\left(15^{\circ} \mathrm{C}\right)$ temperature every $12 \mathrm{~h}$, and the stage of the animals at the time of shift was noted. GFP expression was scored $24 \mathrm{~h}$ after the L4/adult transition under 400x magnification. In the case of adult shifts, animals were raised at either $15^{\circ} \mathrm{C}$ or $25^{\circ} \mathrm{C}$ until the adult stage. Animals were then shifted to the restrictive or permissive temperatures, and GFP expression was scored every $24 \mathrm{~h}$ under $400 \times$ magnification. Statistical analysis was performed using Statview 4.5.

\section{Acknowledgments}

We are grateful to Maura Berkeley and Julia Thompson for technical assistance; the Caenorhabditis Genetics Center and members of the C. elegans community for strains and reagents; Andy Fire, Jim Thomas, Garth Patterson, and Anne Hart for plasmids; and Mike Chao and Anne Hart for assistance with laser ablation experiments. We thank Oliver Hobert and members of the Sengupta lab for critical comments on the manuscript and the Sengupta lab for advice and ideas. This work was funded in part by the NIH and NSF (GM56223 and IBN 0129370) and the Packard Foundation (P.S.). K.M.N. was supported by funds from the NIH (F32 DC05310). T.S.-R. was a predoctoral fellow of the Howard Hughes Medical Institute.

The publication costs of this article were defrayed in part by payment of page charges. This article must therefore be hereby marked "advertisement" in accordance with 18 USC section 1734 solely to indicate this fact.

\section{References}

Albert, P.S. and Riddle, D.L. 1983. Developmental alterations in sensory neuroanatomy of the Caenorhabditis elegans dauer larva. J. Comp. Neurol. 219: 461-481.
Albert, P.S., Brown, S.J., and Riddle, D.L. 1981. Sensory control of dauer larva formation in Caenorhabditis elegans. J. Comp. Neurol. 198: 435-451.

Avery, L. and Horvitz, H.R. 1989. Pharyngeal pumping continues after laser killing of the pharyngeal nervous system of $C$. elegans. Neuron 3: 473-485.

Bailey, C.H. and Chen, M. 1988. Long-term memory in Aplysia modulates the total number of varicosities of single identified sensory neurons. Proc. Natl. Acad. Sci. 85: 2373-2377.

Baird, S.E. and Ellazar, S.A. 1999. TGF- $\beta$-like signaling and spicule development in Caenorhabditis elegans. Dev. Biol. 212: 93-100.

Baran, R., Aronoff, R., and Garriga, G. 1999. The C. elegans homeodomain gene unc-42 regulates chemosensory and glutamate receptor expression. Development 126: 2241-2251.

Bargmann, C.I. and Mori, I. 1997. Chemotaxis and thermotaxis. In C. elegans II (eds. D.S. Riddle et al.), pp. 717-737. Cold Spring Harbor Laboratory Press, Cold Spring Harbor, NY.

Barth, A.L., Justice, N.J., and Ngai, J. 1996. Asynchronous onset of odorant receptor expression in the developing zebrafish olfactory system. Neuron 16: 23-34.

Bernhard, N. and van der Kooy, D. 2000. A behavioral and genetic dissection of two forms of olfactory plasticity in Caenorhabditis elegans: Adaptation and habituation. Learn. Mem. 7: 199-212.

Brennan, P.A. and Keverne, E.B. 1997. Neural mechanisms of mammalian olfactory learning. Prog. Neurobiol. 51: 457481.

Brenner, S. 1974. The genetics of Caenorhabditis elegans. Genetics 77: 71-94.

Chalfie, M. and Sulston, J. 1981. Developmental genetics of the mechanosensory neurons of Caenorhabditis elegans. Dev. Biol. 82: 358-370.

Chess, A., Simon, I., Cedar, H., and Axel, R. 1994. Allelic inactivation regulates olfactory receptor gene expression. Cell 78: 823-834.

Clyne, P.J., Warr, C.G., Freeman, M.R., Lessing, D., Kim, J., and Carlson, J.R. 1999. A novel family of divergent seven-transmembrane proteins: Candidate odorant receptors in Drosophila. Neuron 22: 327-338.

Coburn, C. and Bargmann, C.I. 1996. A putative cyclic nucleotide-gated channel is required for sensory development and function in C. elegans. Neuron 17: 695-706.

Colavita, A., Krishna, S., Zheng, H., Padgett, R.W., and Culotti, J.G. 1998. Pioneer axon guidance by UNC-129, a C. elegans TGF- $\beta$. Science 281: 706-709.

Colbert, H.A. and Bargmann, C.I. 1995. Odorant-specific adaptation pathways generate olfactory plasticity in C. elegans. Neuron 14: 803-812.

. 1997. Environmental signals modulate olfactory acuity, discrimination, and memory in Caenorhabditis elegans. Learn. Mem. 4: 179-191.

Colbert, H.A., Smith, T.L., and Bargmann, C.I. 1997. OSM-9, a novel protein with structural similarity to channels, is required for olfaction, mechanosensation, and olfactory adaptation in Caenorhabditis elegans. I. Neurosci. 17: 82598269.

Corish, P. and Tyler-Smith, C. 1999. Attenuation of green fluorescent protein half-life in mammalian cells. Protein Eng. 12: $1035-1040$.

Dubin, A.E., Heald, N.L., Cleveland, B., Carlson, J.R., and Harris, G.L. 1995. Scutoid mutation of Drosophila melanogaster specifically decreases olfactory responses to short-chain acetate esters and ketones. J. Neurobiol. 28: 214-233.

Dwyer, N.D., Troemel, E.R., Sengupta, P., and Bargmann, C.I. 1998. Odorant receptor localization to olfactory cilia is me- 
diated by ODR-4, a novel membrane-associated protein. Cell 93: 455-466.

Estevez, M., Attisano, L., Wrana, J.L., Albert, P.S., Massague, J., and Riddle, D.L. 1993. The daf-4 gene encodes a bone morphogenetic protein receptor controlling C. elegans dauer larva development. Nature 365: 644-649.

Fain, G.L., Matthews, H.R., Cornwall, M.C., and Koutalos, Y. 2001. Adaptation in vertebrate photoreceptors. Physiol. Rev. 81: 117-151.

Finkbeiner, S. and Greenberg, M.E. 1998. $\mathrm{Ca}^{2+}$ channel-regulated neuronal gene expression. J. Neurobiol. 37: 171-189.

Fox, A.N., Pitts, R.J., Robertson, H.M., Carlson, J.R., and Zwiebel, L.J. 2001. Candidate odorant receptors from the malaria vector mosquito Anopheles gambiae and evidence of downregulation in response to blood feeding. Proc. Natl. Acad. Sci. 98: 14693-14697.

Gao, Q. and Chess, A. 1999. Identification of candidate Drosophila olfactory receptors from genomic DNA sequence. Genomics 60: 31-39.

Georgi, L.K., Albert, P.S., and Riddle, D.L. 1990. daf-1, a C. elegans gene controlling dauer larva development, encodes a novel receptor protein kinase. Cell 61: 635-645.

Golden, J.W. and Riddle, D.L. 1982. A pheromone influences larval development in the nematode Caenorhabditis elegans. Science 218: 578-580.

- 1984. The Caenorhabditis elegans dauer larva: Developmental effects of pheromone, food, and temperature. Dev. Biol. 102: 368-378.

Gottlieb, S. and Ruvkun, G. 1994. daf-2, daf-16 and daf-23: Genetically interacting genes controlling dauer formation in Caenorhabditis elegans. Genetics 137: 107-120.

Hart, A.C., Kass, J., Shapiro, J.E., and Kaplan, J.M. 1999. Distinct signaling pathways mediate touch and osmosensory responses in a polymodal sensory neuron. I. Neurosci. 19: $1952-1958$.

Hedgecock, E.M. and Russell, R.L. 1975. Normal and mutant thermotaxis in the nematode Caenorhabditis elegans. Proc. Nat1. Acad. Sci. 72: 4061-4065.

Herman, R.K. and Hedgecock, E.M. 1990. Limitation of the size of the vulval primordium of Caenorhabditis elegans by lin15 expression in surrounding hypodermis. Nature 348: 169171.

Hsieh, J., Liu, J., Kostas, S.A., Chang, C., Sternberg, P.W., and Fire, A. 1999. The RING finger/B-box factor TAM-1 and a retinoblastoma-like protein LIN-35 modulate context-dependent gene silencing in Caenorhabditis elegans. Genes \& Dev. 13: 2958-2970.

Impey, S., Smith, D.M., Obrietan, K., Donahue, R., Wade, C., and Storm, D.R. 1998. Stimulation of cAMP response element (CRE)-mediated transcription during contextual learning. Nat. Neurosci. 1: 595-601.

Inoue, T. and Thomas, J.H. 2000. Targets of TGF- $\beta$ signaling in Caenorhabditis elegans dauer formation. Dev. Biol. 217: 192-204.

Kendrick, K.M., Levy, F., and Keverne, E.B. 1992. Changes in the sensory processing of olfactory signals induced by birth in sheep. Science 256: 833-836.

Komatsu, H., Mori, I., and Ohshima, Y. 1996. Mutations in a cyclic nucleotide-gated channel lead to abnormal thermosensation and chemosensation in C. elegans. Neuron 17: 707-718.

Lanjuin, A. and Sengupta, P. 2002. Regulation of chemosensory receptor expression and sensory signaling by the KIN-29 Ser/ Thr kinase. Neuron 33: 369-381.

L'Etoile, N.D. and Bargmann, C.I. 2000. Olfaction and odor discrimination are mediated by the C. elegans guanylyl cyclase
ODR-1. Neuron 25: 575-586.

Li, X., Zhao, X., Fang, Y., Jiang, X., Duong, T., Fan, C., Huang, C.C., and Kain, S.R. 1998. Generation of destabilized green fluorescent protein as a transcription reporter. J. Biol. Chem. 273: 34970-34975.

Malnic, B., Hirono, J., Sato, T., and Buck, L.B. 1999. Combinatorial receptor codes for odors. Cell 96: 713-723.

Malone, E.A. and Thomas, J.H. 1994. A screen for nonconditional dauer-constitutive mutations in Caenorhabditis elegans. Genetics 136: 879-886.

Mezler, M., Konzelmann, S., Freitag, J., Rossler, P., and Breer, H. 1999. Expression of olfactory receptors during development in Xenopus laevis. J. Exp. Biol. 202: 365-376.

Miyabayashi, T., Palfreyman, M.T., Sluder, A.E., Slack, F., and Sengupta, P. 1999. Expression and function of members of a divergent nuclear receptor family in Caenorhabditis elegans. Dev. Biol. 215: 314-331.

Morgan, S.M., Butz Huryn, V.M., Downes, S.R., and Mercer, A.R. 1998. The effects of queenlessness on the maturation of the honey bee olfactory system. Behav. Brain. Res. 91: 115126.

Morrison, G.E., Wen, J.Y., Runciman, S., and van der Kooy, D. 1999. Olfactory associative learning in Caenorhabditis elegans is impaired in $7 r n-1$ and $7 r n-2$ mutants. Behav. Neurosci. 113: 358-367.

Peckol, E.L., Troemel, E.R., and Bargmann, C.I. 2001. Sensory experience and sensory activity regulate chemosensory receptor gene expression in C. elegans. Proc. Natl. Acad. Sci. 98: $11032-11038$.

Pham, T.A., Impey, S., Storm, D.R., and Stryker, M.P. 1999. CRE-mediated gene transcription in neocortical neuronal plasticity during the developmental critical period. Neuron 22: 63-72.

Pierce, S.B., Costa, M., Wisotzkey, R., Devadhar, S., Homburger, S.A., Buchman, A.R., Ferguson, K.C., Heller, J., Platt, D.M., Pasquinelli, A.A., et al. 2001. Regulation of DAF-2 receptor signaling by human insulin and ins-1, a member of the unusually large and diverse C. elegans insulin gene family. Genes \& Dev. 15: 672-686.

Pierce-Shimomura, J.T., Faumont, S., Gaston, M.R., Pearson, B.J., and Lockery, S.R. 2001. The homeobox gene lim-6 is required for distinct chemosensory representations in C. elegans. Nature 410: 694-698.

Ren, P., Lim, C.S., Johnsen, R., Albert, P.S., Pilgrim, D., and Riddle, D.L. 1996. Control of C. elegans larval development by neuronal expression of a TGF- $\beta$ homolog. Science 274: $1389-1391$.

Riddle, D.L. and Albert, P.S. 1997. Genetic and environmental regulation of dauer larva development. In C. elegans II (eds. D.S. Riddle et al.), pp. 739-768. Cold Spring Harbor Press, Cold Spring Harbor, NY.

Roayaie, K., Crump, J.G., Sagasti, A., and Bargmann, C.I. 1998. The Ga protein ODR-3 mediates olfactory and nociceptive function and controls cilium morphogenesis in C. elegans olfactory neurons. Neuron 20: 55-67.

Robertson, H.M. 1998. Two large families of chemoreceptor genes in the nematodes Caenorhabditis elegans and Caenorhabditis briggsae reveal extensive gene duplication, diversification, movement, and intron loss. Genome Res. 8: $449-463$.

2000. The large srh family of chemoreceptor genes in Caenorhabditis nematodes reveals processes of genome evolution involving large duplications and deletions and intron gains and losses. Genome Res. 10: 192-203.

Ruvkun, G. and Hobert, O. 1998. The taxonomy of developmental control in Caenorhabditis elegans. Science 282: 2033- 
2041.

Sagasti, A., Hobert, O., Troemel, E.R., Ruvkun, G., and Bargmann, C.I. 1999. Alternative olfactory neuron fates are specified by the LIM homeobox gene lim-4. Genes \& Dev. 13: $1794-1806$.

Sarafi-Reinach, T.R. and Sengupta, P. 2000. The forkhead domain gene unc-130 generates chemosensory neuron diversity in C. elegans. Genes \& Dev. 14: 2472-2485.

Sarafi-Reinach, T.R., Melkman, T., Hobert, O., and Sengupta, P. 2001. The lin-11 LIM homeobox gene specifies olfactory and chemosensory neuron fates in C. elegans. Development 128: $3269-3281$.

Satterlee, J.S., Sasakura, H., Kuhara, A., Berkeley, M., Mori, I., and Sengupta, P. 2001. Specification of thermosensory neuron fate in C. elegans requires $t t x-1$, a homolog of otd/Otx. Neuron 31: 943-956.

Schackwitz, W.S., Inoue, T., and Thomas, J.H. 1996. Chemosensory neurons function in parallel to mediate a pheromone response in C. elegans. Neuron 17: 719-728.

Scott, K., Brady. R, Cravchik, A., Morozov, P., Rzhetsky, A., Zuker, C., and Axel, R. 2001. A chemosensory gene family encoding candidate gustatory and olfactory receptors in Drosophila. Cell 104: 661-673.

Sengupta, P., Colbert, H.A., and Bargmann, C.I. 1994. The C. elegans gene odr-7 encodes an olfactory-specific member of the nuclear receptor superfamily. Cell 79: 971-980.

Sengupta, P., Chou, J.H., and Bargmann, C.I. 1996. odr-10 encodes a seven transmembrane domain olfactory receptor required for responses to the odorant diacetyl. Cell 84: 899909.

Shaver, S.A., Varnam, C.J., Hilliker, A.J., and Sokolowski, M.B. 1998. The foraging gene affects adult but not larval olfactoryrelated behavior in Drosophila melanogaster. Behav. Brain Res. 95: 23-29.

Sulston, J.E., Schierenberg, E., White, J.G., and Thomson, J.N. 1983. The embryonic cell lineage of the nematode Caenorhabditis elegans. Dev. Biol. 100: 64-119.

Suzuki, Y., Yandell, M.D., Roy, P.J., Krishna, S., Savage-Dunn, C., Ross, R.M., Padgett, R.W., and Wood, W.B. 1999. A BMP homolog acts as a dose-dependent regulator of body size and male tail patterning in Caenorhabditis elegans. Development 126: 241-250.

Thomas, J.H., Birnby, D.A., and Vowels, J.J. 1993. Evidence for parallel processing of sensory information controlling dauer formation in Caenorhabditis elegans. Genetics 134: 1105 1117.

Trent, C., Tsung, N., and Horvitz., H.R. 1983. Egg-laying defective mutants of the nematode Caenorhabditis elegans. Genetics 104: 619-647.

Troemel, E.R. 1999a. "Chemosensory receptors in Caenorhabditis elegans." Ph.D. thesis, University of California, San Francisco.

-1999b. Chemosensory signaling in C. elegans. Bioessays 21: 1011-1020.

Troemel, E.R., Chou, J.H., Dwyer, N.D., Colbert, H.A., and Bargmann, C.I. 1995. Divergent seven transmembrane receptors are candidate chemosensory receptors in C. elegans. Cell 83: 207-218.

Troemel, E.R., Kimmel, B.E., and Bargmann, C.I. 1997. Reprogramming chemotaxis responses: sensory neurons define olfactory preferences in C. elegans. Cell 91: 161-169.

Troemel, E.R., Sagasti, A., and Bargmann, C.I. 1999. Lateral signaling mediated by axon contact and calcium entry regulates asymmetric odorant receptor expression in C. elegans. Cell 99: 387-398.

Van Swinderen, B., Metz, L.B., Shebester, L.D., and Crowder,
C.M. 2002. A Caenorhabditis elegans pheromone antagonizes volatile anesthetic action through a $\mathrm{G}_{0}$-coupled pathway. Genetics 161: 109-119.

Vosshall, L.B., Amrein, H., Morozov, P.S., Rzhetsky, A., and Axel, R. 1999. A spatial map of olfactory receptor expression in the Drosophila antenna. Cell 96: 725-736.

Vowels, J.J. and Thomas, J.H. 1992. Genetic analysis of chemosensory control of dauer formation in Caenorhabditis elegans. Genetics 130: 105-123.

. 1994. Multiple chemosensory defects in daf-11 and daf21 mutants of Caenorhabditis elegans. Genetics 138: 303316.

Wang, H.-W., Wysocki, C.J., and Gold, G.H. 1993. Induction of olfactory receptor sensitivity in mice. Science 260: 9981000.

Wen, J.Y., Kumar, N., Morrison, G., Rambaldini, G., Runciman, S., Rousseau, J., and van der Kooy, D. 1997. Mutations that prevent associative learning in C. elegans. Behav. Neurosci, 111: 354-368.

Yin, J.C., Wallach, J.S., Del Vecchio, M., Wilder, E.L., Zhou, H., Quinn, W.G., and Tully, T. 1994. Induction of a dominant negative CREB transgene specifically blocks long-term memory in Drosophila. Cell 79: 49-58.

Zufall, F. and Leinders-Zufall, T. 2000. The cellular and molecular basis of odor adaptation. Chem. Senses 25: 473-481. 


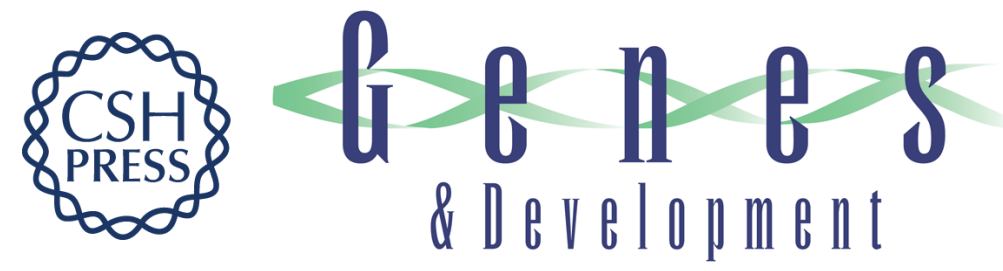

\section{The DAF-7 TGF- $\beta$ signaling pathway regulates chemosensory receptor gene expression in C. elegans}

Katherine M. Nolan, Trina R. Sarafi-Reinach, Jennifer G. Horne, et al.

Genes Dev. 2002, 16:

Access the most recent version at doi:10.1101/gad.1027702

Supplemental http://genesdev.cshlp.org/content/suppl/2002/12/05/16.23.3061.DC1
Material

References This article cites 81 articles, 33 of which can be accessed free at: http://genesdev.cshlp.org/content/16/23/3061.full.html\#ref-list-1

License

Email Alerting Receive free email alerts when new articles cite this article - sign up in the box at the top Service right corner of the article or click here.

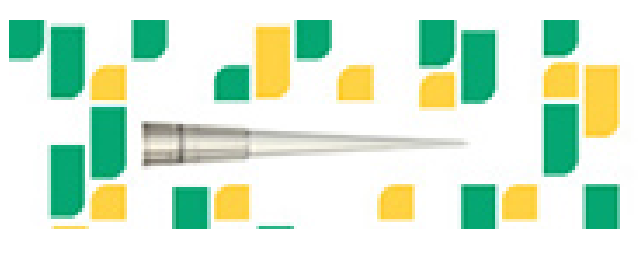

